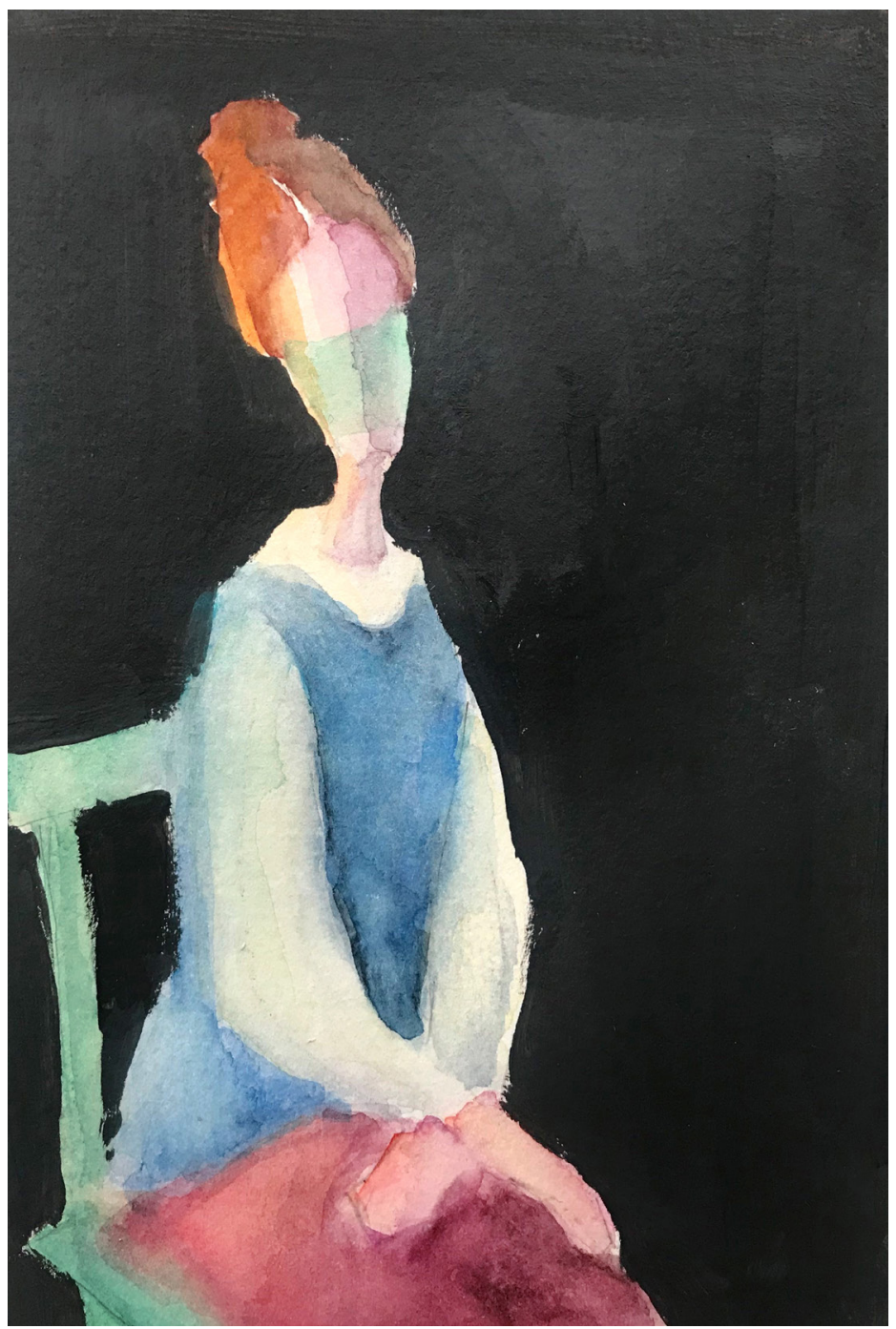

\title{
Jean Hebuterne con coronavirus
}

\section{Reflexión}

El arte como herramienta que permite promover y activar pensamientos me ha llevado a utilizar la obra de Modigliani, a modo de pintura apropiacionista, para reinterpretarla, siendo la figura de Jean Hebuterne dónde me recreo y con la que quiero comunicar sentimientos de impotencia frente a acontecimientos que no está de tu mano resolver.

\section{Autora}

Teresa Muñoz. Licenciada: Bellas artes (Universidad Complutense de Madrid). Dirige el taller de Arteterapia en un Centro Ocupacional de discapacitados psíquicos perteneciente a la comunidad de Madrid.

Arteterapia: papeles de arteterapia y educación artística para la integración social.

Monográfico: Las miradas del arte y el arteterapia en tiempos de la Covid19. ISSN-e: 1988-8309 https://dx.doi.org/10.5209/arte.75881 